\title{
Evaluation of Nutritional and Antinutritional Properties of African Yam Bean (Sphenostylis stenocarpa (Hochst ex. A. Rich.) Harms.) Seeds
}

\author{
Taofeek T. Adegboyega (D), ${ }^{1,2}$ Michael T. Abberton ${ }^{(D)},{ }^{1}$ AbdelAziz H. AbdelGadir, ${ }^{3}$ \\ Mahamadi Dianda, ${ }^{3}$ Busie Maziya-Dixon, ${ }^{4}$ Olaniyi A. Oyatomi, ${ }^{1}$ Sam Ofodile, ${ }^{5}$ \\ and Olubukola O. Babalola (iD $^{2}$ \\ ${ }^{1}$ Genetic Resources Center, International Institute of Tropical Agriculture (IITA), Oyo Road, Ibadan, Nigeria \\ ${ }^{2}$ Food Security and Safety Niche, Faculty of Natural and Agricultural Science, North-West University, Private Mail Bag X2046, \\ Mmabatho 2735, South Africa \\ ${ }^{3}$ Soil Microbiology Laboratory, IITA, Ibadan, Nigeria \\ ${ }^{4}$ Food and Nutrition Sciences Laboratory, IITA, Ibadan, Nigeria \\ ${ }^{5}$ Biometrics Unit, IITA, Ibadan, Nigeria
}

Correspondence should be addressed to Taofeek T. Adegboyega; t.adegboyega@cgiar.org and Michael T. Abberton; m.abberton@cgiar.org

Received 4 February 2020; Revised 20 May 2020; Accepted 6 June 2020; Published 27 June 2020

Academic Editor: Antimo Di Maro

Copyright (C) 2020 Taofeek T. Adegboyega et al. This is an open access article distributed under the Creative Commons Attribution License, which permits unrestricted use, distribution, and reproduction in any medium, provided the original work is properly cited.

\begin{abstract}
African yam bean (Sphenostylis stenocarpa (Hochst ex. A. Rich.) Harms) is an annual legume with the capacity to produce bean seeds in a pod and produce tubers with varying seed patterns and colors. It is suggested to have the potential to significantly boost food security in sub-Saharan Africa due to its considerable nutritional qualities but still yet underutilized. Many farmers show limited interest in its production owing to limited knowledge of its nutritional profile, income generation capacity for smallholder farmers', processing, and other related utilization concerns. This study evaluated the proximate and antinutrient composition of processed and unprocessed seeds of African yam bean (Sphenostylis stenocarpa (Hochst ex. A. Rich.) Harms.). Seeds were harvested from the experimental research field consisting of 50 accessions at the International Institute of Tropical Agriculture (IITA), Ibadan, Nigeria. They were divided into two portions; the first was processed by oven drying at $60^{\circ} \mathrm{C}$ for 24 hours and the second was left raw. There were significant differences $(P<0.05)$ in the levels of proximate and antinutrient in the forms in which the samples were analyzed. TSs 104 had the highest protein content of $25.08 \%$, while the lowest was TSs68 (20.50\%). However, in the unprocessed seed, protein content ranged between 24.93\% (TSs38) and 19.13\% (TSs11). Both processed and unprocessed seeds had high carbohydrate contents. In processed seeds, TSs9 $(62.93 \%)$ had the highest percentage and TSs1 (29.64\%) recorded the lowest. In unprocessed seed, the percentage ranged between $67.36 \%$ (TSs4) and 54.23\% (TSs38). The observed variation may suggest possible suitability of seed for various end-use products and targeted breeding programs for crop improvements. In sub-Saharan Africa, this lesser-known legume could be adapted as a promising food crop in combating proteinenergy malnutrition.
\end{abstract}

\section{Introduction}

Legumes are adaptable under unfavorable ecological conditions, nutritious, and stress tolerant, possessing features for enhancing the sustainability of dry subtropical and tropical agricultural systems [1]. They fit in various cropping systems owing to their wide flexibility, low input requirements, and potential for nitrogen fixing and weed reduction. Their short growing period and photoperiod sensitivity make them more suitable for crop intensification and 
diversification [2]. This attribute made the Romans initiate crop rotation and the cultivation of leguminous crops used for green manuring [3]. Legumes possess some significant health protective compounds such as phenolics and are considered to be an inexpensive dietary source of protein, minerals, carbohydrates, and vitamins. They have high nutritive value and contain, on average, about twice as much protein as cereals [4]. In some countries, complementary diets based on cereals, tubers, and roots along with legumes are recommended as the best solution for undernourishment. This shows that legumes have a significant role in improving the nutritional status of a malnourished population particularly in sub-Saharan Africa [5]. However, in many developing countries underutilized legumes are found among crops with economic potential constrained by several factors such as limited global economic value, neglect by research and development projects, and agronomic concerns [6-10]. They can also be used as animal feed and in other agricultural activities to generate income for small-holder farmers. They are grown to support families, offer high nutritional value, and are currently neglected and sparsely documented [4, 11-16].

Orphan legumes (OL) are predominant in various communities with significant properties but have gained less attention when compared to major staple crops [17]. Challenges such as the use of available germplasm and seed supply constraints are part of the limiting opportunities but they play a crucial role in income generation to local farmers and nutrient availability to consumers. In the global market, OL have been neglected by members of the academic/research as well as the commercial industries. Owing to limited preferences, their strong adaptation to extreme soil status and climatic variabilities stand them out for exploitation. OL have been shown to contain compounds that can actively contribute to human and animal health. Many of these compounds have not been fully utilized in providing nutritional support to the malnourished population [18].

African yam bean (Sphenostylis stenocarpa (Hochst ex. A. Rich.)) is one of such crops with significant nutritional potential. However, there is low awareness of its productive and nutritional value. Subsistence production may have been caused by the low acceptability of African yam bean as a valuable crop among middle-aged farmers in Africa [19-21]. It had its origin in Ethiopia but is now widely cultivated in tropical Africa, especially West Africa, in Cameroon, Ghana, and Nigeria [22]. It is grown for seed and tubers to be used as food since it tolerates an annual rainfall of less than $1000 \mathrm{~mm}$ [23]. Some studies have examined various objectives on African yam bean flour from seed sourced from open markets and communities [24-28] but in this present study, seeds were obtained from the germplasm collections and planted at IITA. Data obtained would be useful for prebreeding crop improvement programs and other biotechnology research activities at the Genetic Resources Center of IITA and other research centers or universities working on the lesser-known legume.
TABLE 1: Twenty-five accessions of African yam beans sourced from GRC, IITA.

\begin{tabular}{lcc}
\hline Accession & Origin & Seed color \\
\hline TSs1 & Nigeria & Dark brown \\
TSs3 & Nigeria & Brown \\
TSs4 & Nigeria & Greyish orange \\
TSs9 & Nigeria & Dark brown \\
TSs11 & Nigeria & Greyish yellow \\
TSs16 & Nigeria & Dark brown \\
TSs23 & Nigeria & Brown \\
TSs24 & Nigeria & Light brown \\
TSs27 & Nigeria & Brownish orange \\
TSs30 & Nigeria & Greyish orange \\
TSs33 & Nigeria & Brown \\
TSs38 & Nigeria & Dark blond \\
TSs44 & Nigeria & Olive brown \\
TSs61 & Nigeria & Light brown \\
TSs66 & Bangladesh & Dark brown \\
TSs67 & Bangladesh & Dark violet \\
TSs68 & Zaire & Light brown \\
TSs76 & Ghana & Greenish grey \\
TSs77 & Ghana & Dark brown \\
TSs81 & Nigeria & Light brown \\
TSs82 & Nigeria & Dark brown \\
TSs98 & Nigeria & Reddish blond \\
TSs101 & Nigeria & Brownish orange \\
TSs104 & Nigeria & Olive brown \\
TSs109 & Nigeria & Dark brown \\
\hline & &
\end{tabular}

\section{Materials and Methods}

2.1. Experimental Design. On-station field experiments were conducted using a total of 50 accessions selected based on seed color, previous characterization data, and origin at the International Institute of Tropical Agriculture (IITA) (latitude $7^{\circ} 30^{\prime} 8^{\prime \prime}$; longitude $3^{\circ} 54^{\prime} 37^{\prime \prime}$ ), Ibadan, Nigeria, on an Alfisol soil of the Egbeda series [29]. Monthly rainfall ranged between 0.05 and $86.5 \mathrm{~mm}$; the minimum and maximum temperatures ranged between 20 and $27^{\circ} \mathrm{C}$. Standard seed packaging protocols were used in postharvest seed management. The seed was divided into two portions (25 accessions in each); the first was ovendried (Thermo Scientific, Heratherm OMHT750, Thermo Electron LED $\mathrm{GmbH}$, Germany) at $60^{\circ} \mathrm{C}$ for 24 hours (processed) while the second was left raw (unprocessed). Table 1 shows the passport data of the accessions used for the study.

2.2. Processing and Sample Analysis. The grain of African yam bean was processed into flour and analyzed using the standard laboratory methods described by Alamu et al. [30] for proximate protein, fat, fiber, ash, moisture content (mc), and carbohydrate. The samples were dried at $100-105^{\circ} \mathrm{C}$ for 16 hours in a draft air oven (Thermo Scientific, Heratherm OMHT750, Thermo Electron LED GmbH, Germany) for moisture content determination. The loss in weight was reported as moisture. The ash content was determined where 
crucibles that contain the preweighed samples were placed in a heated furnace ((Fisher Isotemp Muffle Furnace, model $186 \mathrm{~A}$, USA), maintained at a temperature of $600^{\circ} \mathrm{C}$ for 6 hours, and allowed to cool to room temperature in desiccators and weighed. The protein content (\% nitrogen x 6.25) and fat content were (1g was extracted for ether extract determination using diethyl ether determined according to the method of AOAC (2004). A similar method was described by the Association of Official Analytical Chemists (2006). The crude fiber was extracted using FIBERTEC ${ }^{\mathrm{TM}}$ 2010 automated fiber analysis system $(240 \mathrm{~V}, 50 \mathrm{~Hz}$, ISO 6865, 92/89 EEC and AOAC 2002.04, Denmark), Adegunwa et al. [31] for tannin determination [23], and Wheeler and Ferrel [32] for phytic acid analysis [24]. The seed was cleaned and sorted to remove impurities before being oven-dried at $60^{\circ} \mathrm{C}$ for 24 hours. The seed coat was removed by hand. Subsequently, the grain was coarse-milled and winnowed to remove seed coats. The decorticated grain was milled into a fine powder and sieved for processed samples. The unprocessed samples were cleaned and milled until fine flour was also obtained. The samples were appropriately labelled and stored in airtight containers at $4-6^{\circ} \mathrm{C}$ for analysis. The proximate and antinutrient analyses were conducted in duplicate at the Food and Nutrition Sciences Laboratory, IITA, Ibadan, Nigeria.

2.3. Statistical Analysis. General linear model (GLM) procedure of the Statistical Analysis System computer software version 9.4 (SAS, 2019) was used for data analysis. The mean values obtained were from two years of field data, and $F$ values were used to indicate the level of significance and cluster analysis of data obtained.

\section{Results}

3.1. Proximate Composition. All proximate components in the seed (Tables 2 and 3 ) were highly significant $(P<0.0001)$. The highest $\mathrm{mc}$ for processed seeds was recorded in TSs 109 at $9.60 \%$ and the lowest in TSs9 at $4.84 \%$. In the unprocessed seed, mc ranged between $10.83 \%$ (TSs77) and 3.31\% (TSs11). The ash content also showed significant variation as TSs67 had the highest mc (3.94\%) followed by TSs101 (3.84\%); the lowest was found in processed seed for TSs77 (3.20\%). In the unprocessed seed, ash content ranged between 3.99\% (TSs38) and 3.06\% (TSs11). The percentage of fat was low in comparison with other legumes. In the processed seed, it was between $2.38 \%$ (TSs1) and $0.37 \%$ (TSs68); in the unprocessed seed, it ranged between $2.62 \%$ (TSs24) and $1.31 \%$ (TSs4). The protein content of the accessions in the two forms in which the seed was analyzed showed markedly significant differences. TSs104 had the highest protein content of $25.08 \%$ followed by TSs76 (24.82\%), TSs1 (24.52\%), TSs4 (24.31\%), and TSs67 (24.24\%); the accessions with the lowest percentage of protein in the processed seed were TSs30 (22.02\%), TSs23 (21.37\%), TSs23 (21.30\%), TSs66 (20.79\%), and TSs68 (20.50\%). However, in the unprocessed seed, protein content ranged between 24.93\% (TSs38) and 19.13\% (TSs11).
The crude fiber content also showed statistically significant variations $(P<0.05)$. The highest quantity of crude fiber was in the processed seed of TSs77 (20.86\%); the lowest was in TSs1 $(2.78 \%)$; in the unprocessed seed, the fiber content ranged between $7.69 \%$ (TSs23) and 3.20\% (TSs9). Both processed and unprocessed seeds had high carbohydrate content. In processed seed, TSs9 $(62.93 \%)$ had the highest percentage and TSs1 (29.64\%) recorded the lowest. In unprocessed seed, the percentage ranged between $67.36 \%$ (TSs4) and 54.23\% (TSs38).

3.2. Antinutrients. The antinutrient content (phytate and tannin) were statistically significant $(P<0.05)$ in both processed and unprocessed seed. For processed seed, TSs66 had the lowest phytate content of $2.95 \%$; the highest was found in TSs1 (7.08\%); TSs30 (5.86\%) had the highest value for unprocessed seed, and TSs67 (3.18\%) had the lowest. Tannin content for processed seed ranged between $2.45 \%$ (TSs23) and $0.08 \%$ (TSs98); for unprocessed seed, it ranged between $3.88 \%$ (TSs67) and (0.66\% (TSs 82 ). Processing was highly efficient in reducing the levels of phytate and tannin in the samples (Table 4). The proximate content of the processed and unprocessed African yam bean seed was classified by principal component analysis (PCA). The principal components were acquired based on the content of $\mathrm{mc}$, ash, crude protein, fat, crude fiber, and carbohydrate, which were measured by standard laboratory procedures. The model of all samples explained $95.03 \%$ of the principal components, with principal component 1 (PC1) interpreting $90.9 \%$ and principal component 2 (PC2) interpreting 4.13\% of the total variance. The biplot indicated that TSs27, TSs82, TSs1, TSs104, and TSs30 were remarkably separate from other accessions (Figure 1). On the other hand, TSs33, TSs66, TSs101, TSs23, TSs67, and TSs82 were located at PC1 with positive scores for unprocessed samples (Figure 2). The two figures suggested that the nutrient compositions were completely dissimilar and the nutrient compositions of African yam bean seeds when unprocessed (raw) and processed were different from one another. Results obtained showed the multivariate analysis of the tannin and phytate contents of the unprocessed (raw) and processed seeds. We noted that processing reduced the level of the antinutrients to permissible limits and did not interfere with the nutrient levels. Figures 3 and 4 show the multivariate analysis of Prin 1 vs. Prin 2 of the tannin and phytate contents of processed and unprocessed seeds of African yam bean with demonstrable variation of the accessions evaluated.

Hierarchical cluster analysis, a method to quantify the similarity of different African yam bean accessions based on the proximate and antinutrient content, was carried out. The average linkage technique produced three clusters of the 25 processed African yam bean seed (Figure 5) if the phenon line was defined at a distance of $65 \%$, whereby individuals within any cluster were more closely related for nutrient composition. Cluster I (8\%), composed of two accessions (TSs38 and TSs109), has high moisture, crude protein, crude fiber, fat, and carbohydrate content. Cluster II (72\%) was the largest and was composed of 18 accessions (from TSs9 to 
TABLE 2: Proximate composition (mean \pm standard deviation) of processed flour.

\begin{tabular}{|c|c|c|c|c|c|c|}
\hline Accession & MC (\%) & ASH (\%) & FAT (\%) & $\mathrm{CP}(\%)$ & CF (\%) & $\mathrm{CHO}(\%)$ \\
\hline TSs1 & $5.66 \pm 0.21$ & $3.71 \pm 0.01$ & $2.38 \pm 0.17$ & $24.52 \pm 0.25$ & $5.55 \pm 0.00$ & $58.27 \pm 0.00$ \\
\hline TSs101 & $8.69 \pm 0.16$ & $3.84 \pm 0.06$ & $1.40 \pm 0.18$ & $23.94 \pm 0.06$ & $5.66 \pm 0.09$ & $56.48 \pm 0.24$ \\
\hline TSs104 & $9.04 \pm 0.23$ & $3.35 \pm 0.00$ & $1.42 \pm 0.10$ & $25.08 \pm 0.09$ & $5.13 \pm 0.36$ & $55.99 \pm 0.13$ \\
\hline TSs109 & $9.60 \pm 0.36$ & $3.37 \pm 0.02$ & $1.16 \pm 0.08$ & $23.32 \pm 0.64$ & $10.16 \pm 0.59$ & $52.41 \pm 0.98$ \\
\hline TSs11 & $5.24 \pm 0.05$ & $3.70 \pm 0.00$ & $0.83 \pm 0.09$ & $22.79 \pm 0.81$ & $8.13 \pm 1.13$ & $59.32 \pm 1.98$ \\
\hline TSs 16 & $8.22 \pm 0.38$ & $3.70 \pm 0.01$ & $1.24 \pm 0.06$ & $23.78 \pm 0.34$ & $5.60 \pm 0.01$ & $57.47 \pm 0.01$ \\
\hline TSs 23 & $8.32 \pm 0.01$ & $3.70 \pm 0.01$ & $1.24 \pm 0.16$ & $21.30 \pm 0.08$ & $5.69 \pm 0.01$ & $59.77 \pm 0.23$ \\
\hline TSs 24 & $7.78 \pm 0.32$ & $3.67 \pm 0.01$ & $0.92 \pm 0.38$ & $21.37 \pm 0.28$ & $5.04 \pm 0.34$ & $61.23 \pm 0.70$ \\
\hline TSs 27 & $8.30 \pm 0.44$ & $3.30 \pm 0.04$ & $1.58 \pm 0.17$ & $22.99 \pm 0.24$ & $6.07 \pm 0.76$ & $57.77 \pm 0.35$ \\
\hline TSs3 & $5.61 \pm 0.16$ & $3.63 \pm 0.11$ & $2.08 \pm 0.15$ & $23.66 \pm 0.32$ & SNE & SNE \\
\hline TSs 30 & $8.49 \pm 0.19$ & $3.32 \pm 0.03$ & $1.56 \pm 0.08$ & $22.02 \pm 0.07$ & $5.57 \pm 0.62$ & $59.05 \pm 0.30$ \\
\hline TSs33 & $8.12 \pm 0.20$ & $3.67 \pm 0.02$ & $1.11 \pm 0.45$ & $23.69 \pm 0.86$ & $5.67 \pm 0.15$ & $57.76 \pm 0.35$ \\
\hline TSs 38 & $9.40 \pm 0.51$ & $3.42 \pm 0.01$ & $1.34 \pm 0.09$ & $22.50 \pm 0.29$ & $8.33 \pm 0.45$ & $55.03 \pm 0.77$ \\
\hline TSs4 & $5.39 \pm 0.10$ & $3.37 \pm 0.03$ & $1.83 \pm 0.37$ & $24.31 \pm 0.28$ & $4.97 \pm 0.26$ & $60.14 \pm 0.22$ \\
\hline TSs 44 & $8.75 \pm 0.00$ & $3.51 \pm 0.03$ & $1.60 \pm 0.32$ & $22.62 \pm 0.15$ & $6.01 \pm 0.67$ & $58.31 \pm 0.00$ \\
\hline TSs61 & $8.22 \pm 0.02$ & $3.82 \pm 0.01$ & $1.65 \pm 0.26$ & $22.78 \pm 1.07$ & $4.66 \pm 0.30$ & $58.89 \pm 1.15$ \\
\hline TSs66 & $8.49 \pm 0.04$ & $3.53 \pm 0.05$ & $1.46 \pm 0.01$ & $20.79 \pm 0.06$ & $5.52 \pm 0.08$ & $60.22 \pm 0.23$ \\
\hline TSs67 & $8.30 \pm 0.15$ & $3.94 \pm 0.18$ & $0.49 \pm 0.25$ & $24.24 \pm 0.32$ & $5.44 \pm 0.63$ & $57.62 \pm 0.39$ \\
\hline TSs68 & $8.79 \pm 0.14$ & $3.83 \pm 0.04$ & $0.37 \pm 0.18$ & $20.50 \pm 0.37$ & $5.67 \pm 0.05$ & $60.85 \pm 0.04$ \\
\hline TSs76 & $8.65 \pm 0.20$ & $3.60 \pm 0.04$ & $0.39 \pm 0.01$ & $24.82 \pm 0.18$ & $5.24 \pm 0.01$ & $57.31 \pm 0.32$ \\
\hline TSs77 & $8.19 \pm 0.28$ & $3.20 \pm 0.01$ & $1.65 \pm 0.09$ & $22.37 \pm 0.33$ & $20.86 \pm 1.79$ & $43.74 \pm 1.91$ \\
\hline TSs 81 & $8.75 \pm 0.18$ & $3.71 \pm 0.02$ & $1.54 \pm 0.16$ & $23.97 \pm 0.11$ & $5.91 \pm 0.08$ & $56.14 \pm 0.40$ \\
\hline TSs82 & $8.72 \pm 0.25$ & $3.43 \pm 0.05$ & $1.51 \pm 0.01$ & $23.97 \pm 0.11$ & $5.55 \pm 0.11$ & $56.84 \pm 0.19$ \\
\hline TSs9 & $4.84 \pm 0.03$ & $3.32 \pm 0.00$ & $1.16 \pm 0.24$ & $22.96 \pm 0.28$ & $4.79 \pm 0.24$ & $62.93 \pm 0.25$ \\
\hline TSs98 & $8.39 \pm 0.01$ & $3.47 \pm 0.03$ & $1.06 \pm 0.33$ & $22.37 \pm 0.41$ & $4.59 \pm 0.91$ & $60.13 \pm 0.78$ \\
\hline LSD & 0.09 & 0.10 & 0.45 & 0.86 & 0.25 & 0.32 \\
\hline$F$ values & $65.57^{* * *}$ & $33.6^{* * *}$ & $9.87^{* * *}$ & $17.29^{* * *}$ & $58.92^{* * *}$ & $46.41^{* * *}$ \\
\hline
\end{tabular}

$F$ values represent one-way ANOVA, degrees of freedom $(\mathrm{d} f)=24 .{ }^{* * *} P \leq 0.0001, \mathrm{MC}=$ moisture content; $\mathrm{CP}=\mathrm{crude}$ protein; $\mathrm{CF}=\mathrm{crude}$ fiber; $\mathrm{CHO}=$ carbohydrate, $\mathrm{STD}=$ standard deviation, $\mathrm{TS} s=$ tropical Sphenostylis stenocarpa $; \mathrm{SNE}=$ sample not enough. $\mathrm{Phytate}(\mathrm{mg} / 100 \mathrm{~g}), \%$ tannin.

Table 3: Proximate composition (mean \pm standard deviation) of unprocessed flour.

\begin{tabular}{|c|c|c|c|c|c|c|}
\hline Accession & MC (\%) & ASH (\%) & FAT (\%) & CP (\%) & CF (\%) & $\mathrm{CHO}(\%)$ \\
\hline TSs1 & $4.14 \pm 0.01$ & $3.16 \pm 0.11$ & $1.61 \pm 0.44$ & $19.78 \pm 0.70$ & $5.27 \pm 0.95$ & $66.04 \pm 0.29$ \\
\hline TSs101 & $9.95 \pm 0.09$ & $3.64 \pm 0.03$ & $2.18 \pm 0.02$ & $22.74 \pm 0.16$ & $6.25 \pm 0.27$ & $55.23 \pm 0.57$ \\
\hline TSs104 & $10.03 \pm 0.05$ & $3.10 \pm 0.30$ & $1.77 \pm 0.05$ & $19.39 \pm 1.90$ & $5.35 \pm 0.29$ & $60.35 \pm 2.60$ \\
\hline TSs109 & $10.28 \pm 0.04$ & $3.42 \pm 0.03$ & $1.58 \pm 0.08$ & $21.39 \pm 0.20$ & $5.26 \pm 0.25$ & $58.08 \pm 0.53$ \\
\hline TSs11 & $3.31 \pm 0.05$ & $3.06 \pm 0.01$ & $1.55 \pm 0.07$ & $19.13 \pm 0.06$ & $5.89 \pm 0.23$ & $67.06 \pm 0.18$ \\
\hline TSs16 & $10.06 \pm 0.08$ & $3.42 \pm 0.04$ & $1.70 \pm 0.49$ & $21.37 \pm 0.26$ & $5.58 \pm 0.26$ & $57.87 \pm 0.97$ \\
\hline TSs23 & $9.89 \pm 0.05$ & $3.51 \pm 0.08$ & $1.80 \pm 0.19$ & $21.93 \pm 0.48$ & $7.69 \pm 2.65$ & $55.19 \pm 2.33$ \\
\hline TSs24 & $10.54 \pm 0.02$ & $3.41 \pm 0.00$ & $2.62 \pm 0.07$ & $21.34 \pm 0.02$ & $5.35 \pm 0.15$ & $56.72 \pm 0.09$ \\
\hline TSs27 & $10.34 \pm 0.03$ & $3.25 \pm 0.02$ & $1.50 \pm 0.16$ & $20.33 \pm 0.11$ & $5.50 \pm 0.26$ & $59.07 \pm 0.25$ \\
\hline TSs3 & $4.19 \pm 0.03$ & $3.06 \pm 0.04$ & $1.91 \pm 0.16$ & $19.15 \pm 0.24$ & $4.66 \pm 0.11$ & $67.03 \pm 0.52$ \\
\hline TSs30 & $9.75 \pm 0.06$ & $3.37 \pm 0.01$ & $1.85 \pm 0.09$ & $21.04 \pm 0.07$ & $4.79 \pm 0.18$ & $59.20 \pm 0.25$ \\
\hline TSs33 & $9.36 \pm 0.08$ & $3.32 \pm 0.01$ & $2.10 \pm 0.14$ & $20.76 \pm 0.05$ & $5.31 \pm 0.28$ & $59.16 \pm 0.01$ \\
\hline TSs38 & $9.83 \pm 0.00$ & $3.99 \pm 0.05$ & $1.34 \pm 0.28$ & $24.93 \pm 0.29$ & $5.68 \pm 0.13$ & $54.23 \pm 0.08$ \\
\hline TSs4 & $4.21 \pm 0.01$ & $3.08 \pm 0.06$ & $1.31 \pm 0.18$ & $19.26 \pm 0.37$ & $4.77 \pm 0.08$ & $67.36 \pm 0.52$ \\
\hline TSs 44 & $9.88 \pm 0.20$ & $3.38 \pm 0.04$ & $1.42 \pm 0.06$ & $21.16 \pm 0.24$ & $4.76 \pm 0.21$ & $59.41 \pm 0.08$ \\
\hline TSs61 & $10.10 \pm 0.02$ & $3.67 \pm 0.03$ & $1.62 \pm 0.08$ & $22.95 \pm 0.17$ & $5.98 \pm 0.22$ & $55.68 \pm 0.48$ \\
\hline TSs66 & $10.07 \pm 0.05$ & $3.42 \pm 0.01$ & $2.00 \pm 0.13$ & $21.40 \pm 0.04$ & $5.42 \pm 0.09$ & $57.69 \pm 0.04$ \\
\hline TSs67 & $9.99 \pm 0.13$ & $3.47 \pm 0.02$ & $1.87 \pm 0.02$ & $21.71 \pm 0.12$ & $5.06 \pm 0.28$ & $57.90 \pm 0.54$ \\
\hline TSs68 & $9.63 \pm 0.01$ & $3.64 \pm 0.02$ & $1.83 \pm 0.17$ & $22.73 \pm 0.15$ & $5.22 \pm 0.33$ & $56.96 \pm 0.01$ \\
\hline TSs76 & $9.86 \pm 0.09$ & $3.59 \pm 0.05$ & $1.53 \pm 0.20$ & $22.45 \pm 0.29$ & $3.96 \pm 0.22$ & $58.60 \pm 0.17$ \\
\hline TSs77 & $10.83 \pm 0.11$ & $3.63 \pm 0.11$ & $1.54 \pm 0.03$ & $22.69 \pm 0.69$ & $5.04 \pm 0.13$ & $56.27 \pm 0.85$ \\
\hline TSs81 & $10.04 \pm 0.04$ & $3.55 \pm 0.01$ & $1.94 \pm 0.12$ & $22.19 \pm 0.06$ & $3.99 \pm 0.37$ & $58.30 \pm 0.37$ \\
\hline TSs82 & $9.60 \pm 0.14$ & $3.48 \pm 0.15$ & $1.80 \pm 0.24$ & $21.78 \pm 0.91$ & $4.90 \pm 0.13$ & $58.44 \pm 1.32$ \\
\hline TSs9 & $4.62 \pm 0.03$ & $3.19 \pm 0.13$ & $1.81 \pm 0.37$ & $19.96 \pm 0.81$ & $3.20 \pm 0.20$ & $67.21 \pm 1.08$ \\
\hline TSs98 & $10.45 \pm 0.16$ & $3.21 \pm 0.06$ & $1.77 \pm 0.40$ & $20.03 \pm 0.39$ & $4.86 \pm 0.36$ & $59.68 \pm 1.38$ \\
\hline LSD & 0.17 & 0.17 & 0.42 & 1.03 & 1.26 & 1.72 \\
\hline$F$ values & $1752.02^{* * *}$ & $16.31^{* * *}$ & $3.94^{* * *}$ & $16.31^{* * *}$ & $3.79^{* *}$ & $47.33^{* * *}$ \\
\hline
\end{tabular}

$F$ values represent one-way ANOVA, degrees of freedom $(\mathrm{d} f)=24 .{ }^{* * *} \mathrm{P} \leq 0.0001, \mathrm{MC}=$ moisture content; $\mathrm{CP}=\mathrm{crude}$ protein; $\mathrm{CF}=\mathrm{crude}$ fiber; $\mathrm{CHO}=$ carbohydrate, $\mathrm{STD}=$ standard deviation, $\mathrm{TS} s=$ tropical Sphenostylis stenocarpa; $\mathrm{SNE}=$ sample not enough. 
TABLE 4: Means \pm standard deviation of antinutrients of processed (P) and unprocessed (UP) African yam bean flour.

\begin{tabular}{|c|c|c|c|c|}
\hline Accession & Tannin $(\%)(\mathrm{P})$ & Phytate $(\mathrm{mg} / 100 \mathrm{~g})(\mathrm{P})$ & Tannin (\%) (UP) & Phytate (mg/100 g) (UP) \\
\hline TSs1 & $2.23 \pm 0.53$ & $7.08 \pm 0.09$ & $2.32 \pm 0.02$ & $4.09 \pm 0.05$ \\
\hline TSs101 & $1.34 \pm 0.37$ & $3.29 \pm 0.05$ & $1.53 \pm 0.52$ & $4.40 \pm 0.05$ \\
\hline TSs104 & $0.00 \pm 0.00$ & $5.27 \pm 0.09$ & $2.13 \pm 0.08$ & $4.23 \pm 0.09$ \\
\hline TSs109 & $0.00 \pm 0.00$ & $4.66 \pm 0.00$ & $2.84 \pm 0.01$ & $4.41 \pm 0.05$ \\
\hline TSs11 & $1.87 \pm 0.31$ & $6.07 \pm 0.11$ & $2.24 \pm 0.06$ & $4.45 \pm 0.28$ \\
\hline TSs16 & $1.02 \pm 0.16$ & $5.42 \pm 0.12$ & $2.47 \pm 0.03$ & $4.29 \pm 0.14$ \\
\hline TSs23 & $2.45 \pm 0.08$ & $4.52 \pm 0.10$ & $1.26 \pm 0.09$ & $3.95 \pm 0.05$ \\
\hline TSs 24 & $0.69 \pm 0.00$ & $4.06 \pm 0.10$ & $3.20 \pm 0.05$ & $3.58 \pm 0.00$ \\
\hline TSs 27 & $1.79 \pm 0.53$ & $5.47 \pm 0.11$ & $3.26 \pm 0.10$ & $3.68 \pm 0.05$ \\
\hline TSs3 & $2.31 \pm 0.15$ & $5.30 \pm 0.04$ & $3.00 \pm 0.12$ & $5.43 \pm 0.05$ \\
\hline TSs30 & $2.09 \pm 0.01$ & $4.72 \pm 0.10$ & $2.38 \pm 0.18$ & $5.86 \pm 0.10$ \\
\hline TSs33 & $0.56 \pm 0.18$ & $4.59 \pm 0.08$ & $2.49 \pm 0.10$ & $3.38 \pm 0.09$ \\
\hline TSs38 & $0.55 \pm 0.63$ & $5.29 \pm 0.05$ & $1.48 \pm 0.20$ & $4.08 \pm 0.14$ \\
\hline TSs4 & $2.07 \pm 0.19$ & $6.57 \pm 0.14$ & $2.24 \pm 0.13$ & $5.00 \pm 0.00$ \\
\hline TSs44 & $0.08 \pm 0.03$ & $5.86 \pm 0.09$ & $3.58 \pm 0.10$ & $3.75 \pm 0.14$ \\
\hline TSs61 & $0.00 \pm 0.00$ & $5.23 \pm 0.13$ & $2.60 \pm 0.06$ & $4.48 \pm 0.33$ \\
\hline TSs66 & $0.00 \pm 0.00$ & $2.95 \pm 0.05$ & $2.69 \pm 0.23$ & $3.45 \pm 0.09$ \\
\hline TSs67 & $0.00 \pm 0.00$ & $4.36 \pm 0.05$ & $3.88 \pm 0.13$ & $3.18 \pm 0.09$ \\
\hline TSs68 & $0.00 \pm 0.00$ & $5.16 \pm 0.05$ & $0.88 \pm 0.06$ & $3.38 \pm 0.09$ \\
\hline TSs76 & $0.00 \pm 0.00$ & $5.87 \pm 0.01$ & $2.99 \pm 0.08$ & $3.24 \pm 0.28$ \\
\hline TSs77 & $0.00 \pm 0.00$ & $4.16 \pm 0.04$ & $2.29 \pm 0.12$ & $3.38 \pm 0.09$ \\
\hline TSs 81 & $0.12 \pm 0.16$ & $3.29 \pm 0.05$ & $2.45 \pm 0.10$ & $4.00 \pm 0.05$ \\
\hline TSs 82 & $0.00 \pm 0.00$ & $4.40 \pm 0.09$ & $0.66 \pm 0.05$ & $4.33 \pm 0.10$ \\
\hline TSs9 & $2.11 \pm 0.01$ & $5.81 \pm 0.09$ & $2.56 \pm 0.06$ & $4.25 \pm 0.09$ \\
\hline TSs98 & $0.08 \pm 0.11$ & $4.73 \pm 0.10$ & $2.16 \pm 0.19$ & $3.64 \pm 0.09$ \\
\hline LSD & 0.47 & 0.17 & 0.3 & 0.27 \\
\hline$F$ value & $33.18^{* * *}$ & $267.69^{* * *}$ & $55.22^{* * *}$ & $50.53^{* * *}$ \\
\hline
\end{tabular}

$F$ values represent one-way ANOVA, degrees of freedom $(\mathrm{d} f)=24 .{ }^{* * *} P \leq 0.0001, \mathrm{STD}=$ standard deviation, TSs $=$ tropical Sphenostylis stenocarpa.

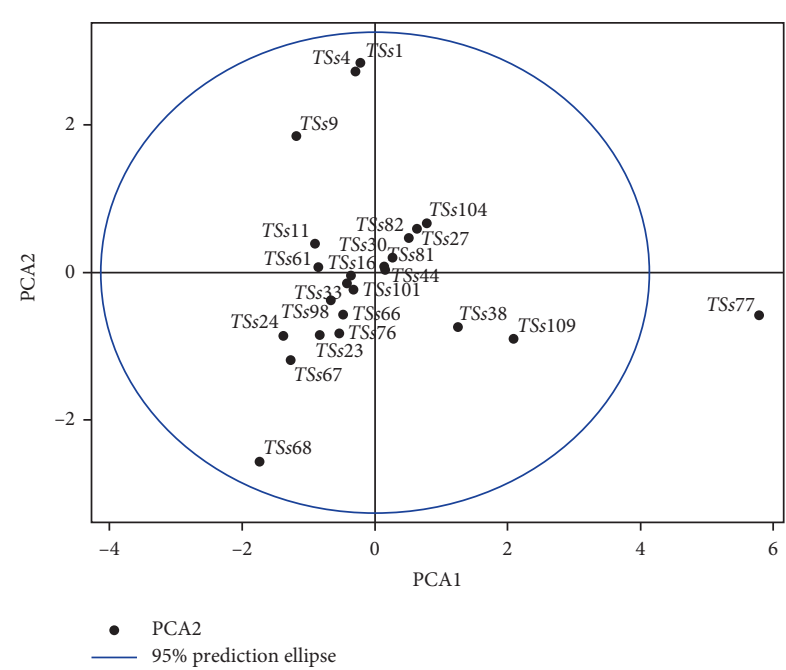

FIGURE 1: Multivariate analysis based on proximate contents of processed samples. PCA: principal component axis; TSs: Tropical Sphenostylis stenocarpa.

TSs101). It has moderate moisture, crude protein, crude fiber, fat, and carbohydrate content. Cluster III (12\%) contained three accessions with low moisture, high crude protein, and carbohydrate content. TSs77 and TSs3 accounted for $4 \%$ and did not fall into any of the clusters. On the other hand, the unprocessed samples (Figure 6) also

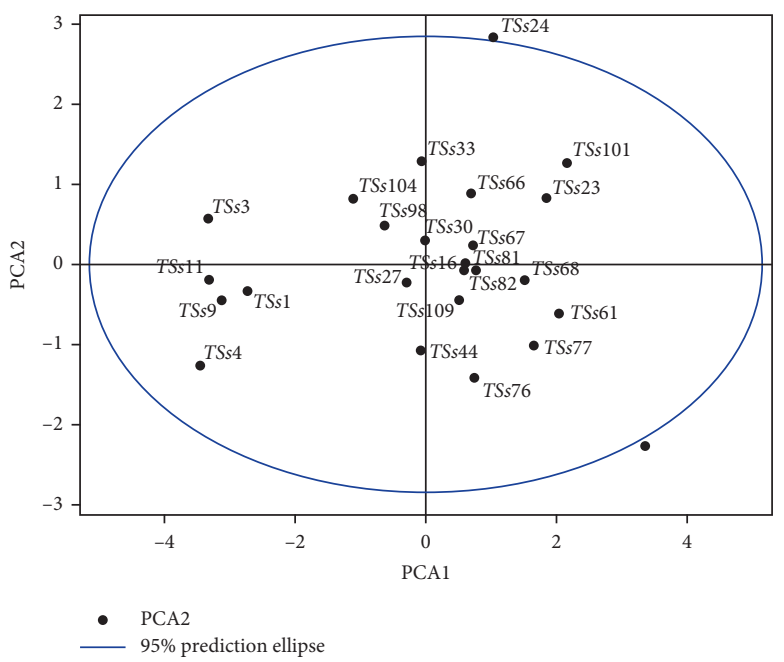

FIGURE 2: Multivariate analysis based on proximate contents of unprocessed samples. PCA: principal component axis; TSs: Tropical Sphenostylis stenocarpa.

consisted of three clusters when the phenon line was defined at a distance of $85 \%$. Cluster I was the largest accounting for $56 \%$ and consisted of TSs 24 to TSs 104 with high moisture, low ash and fat, moderate crude fiber, and high content of crude protein and carbohydrate; cluster II with six accessions (TSs38 to TSs101) accounting for $24 \%$ had high 


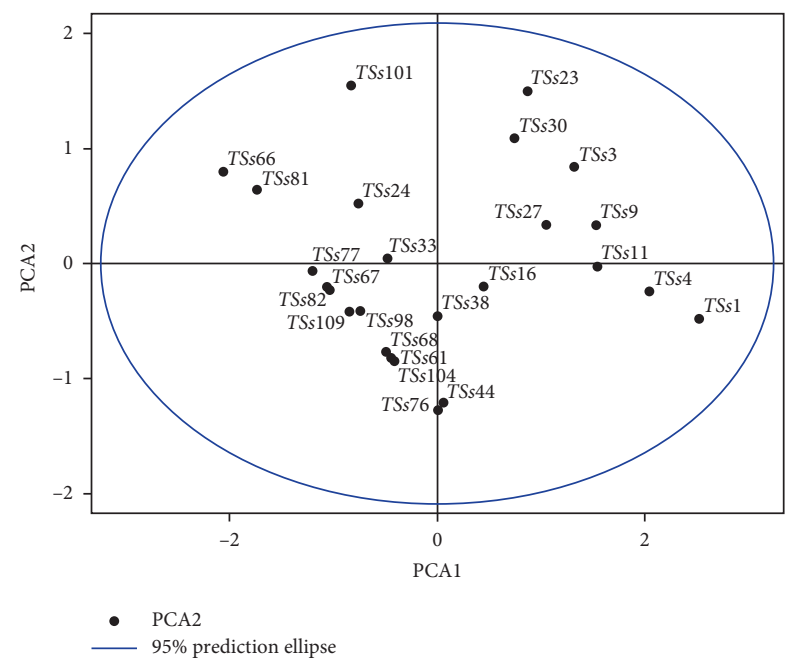

FIGURE 3: Multivariate analysis based on antinutrient contents of processed samples. PCA: principal component axis; TSs: Tropical Sphenostylis stenocarpa.

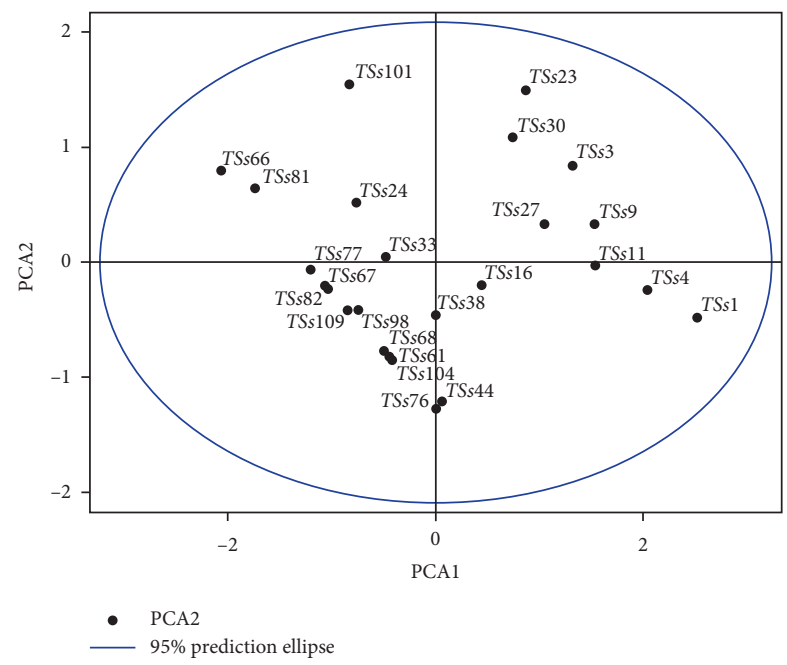

FIGURE 4: Multivariate analysis based on antinutrient contents of unprocessed samples. PCA: principal component axis; TSs: Tropical Sphenostylis stenocarpa.

moisture content, moderate to high ash, fat, crude fiber, crude protein, and carbohydrate. Cluster III, accounting for $20 \%$, consisted of five accessions (TSs9 to TSs1) with low moisture content, high carbohydrate and crude protein, and moderate to high content of ash and fat. Figures 7 and 8 show analyses of the antinutrients for processed and unprocessed samples, respectively. Figure 7 comprises of three clusters. Cluster I with TSs 3 to TSs104 accounting for 56\% was characterized by zero to low tannin and phytate content. Cluster II with TSs1 to TSs101 accounted for 12\% with zero tannin and phytate content; cluster III composed of TSs 30 to TSs 1 accounted for $32 \%$ and also contained accessions with low tannin and phytate.

Figure 8 show the analysis of the unprocessed samples classified into four clusters. Cluster I (8\%) contained TSs30

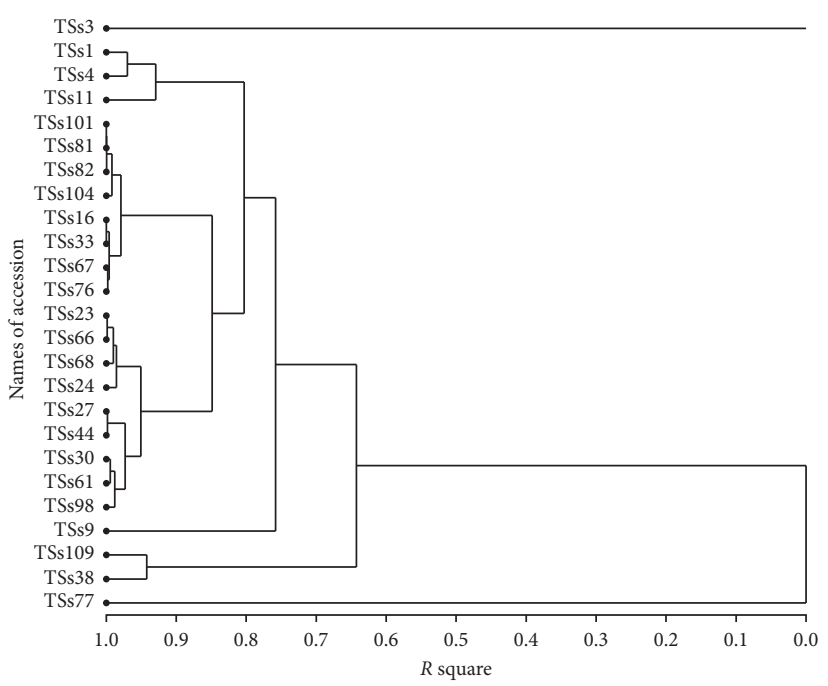

FIGURE 5: Clustering analysis of proximate contents of processed samples. TSs: Tropical Sphenostylis stenocarpa.

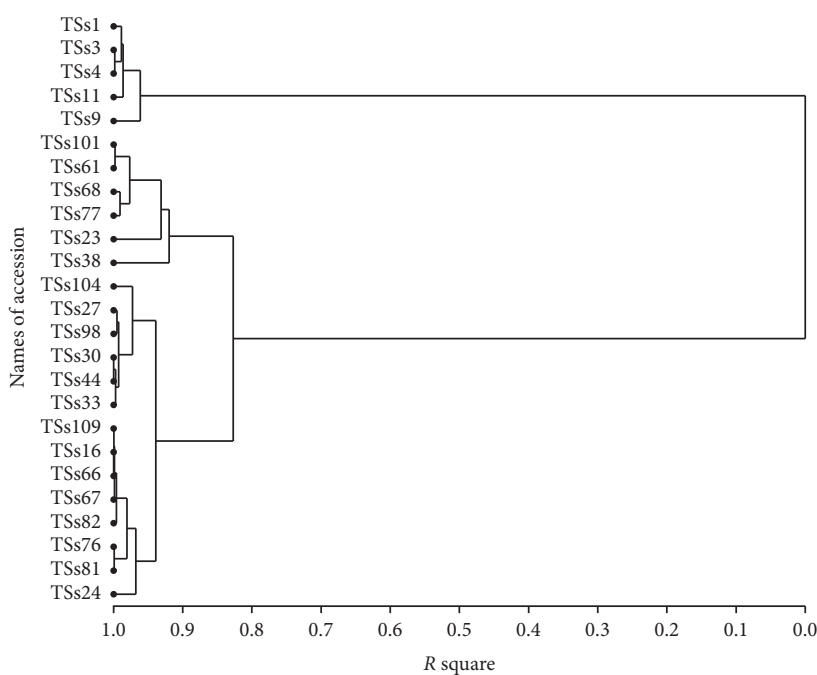

FIgURE 6: Clustering analysis of proximate contents of unprocessed samples. TSs: Tropical Sphenostylis stenocarpa.

to TSs 3 and was characterized by low tannin and high phytate. Cluster II (20\%) was made up of TSs68 to TSs101. Cluster III (TSs67 to TSs33) accounted for 36\% and has low tannin and phytate. Cluster IV contained TSs4 to TSs1, accounted for $36 \%$, and had low tannin and high phytate. The clustering analysis further demonstrated variation among the accessions in relation to processing. These data would be a desirable choice for selecting African yam bean accessions for varietal development/breeding programs. The selection would facilitate the development of cultivars for specific nutritional traits by providing an index of parental lines that may be used in breeding programs.

\section{Discussion}

There were markedly significant differences in the crude protein content of the processed and unprocessed samples. 


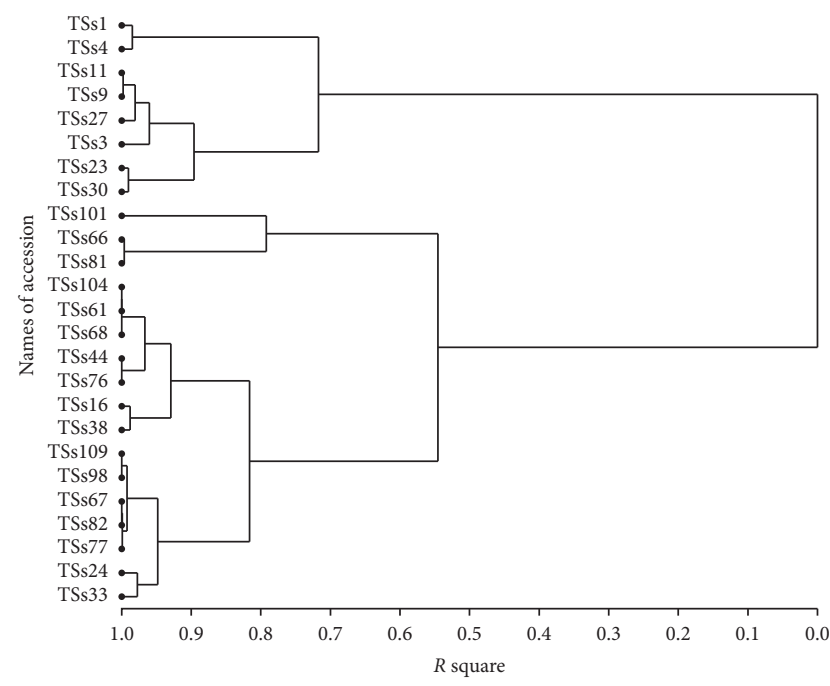

FIGURE 7: Clustering analysis of antinutrients in processed samples. TSs: Tropical Sphenostylis stenocarpa.

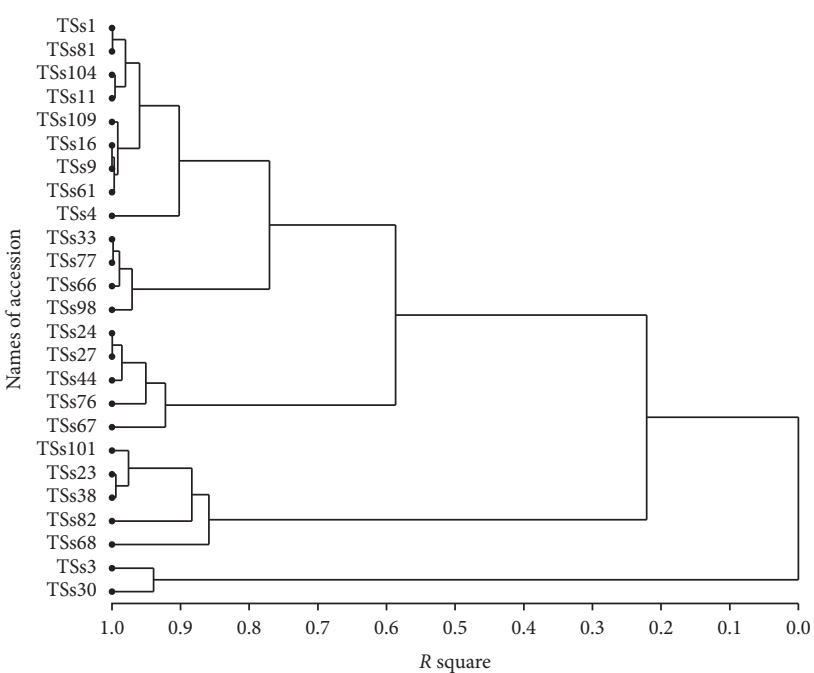

FIGURE 8: Clustering analysis of antinutrients in unprocessed seeds. TSs: Tropical Sphenostylis stenocarpa.

Adegunwa et al. [33] in a related study reported that the level of crude protein for the processed samples was reported to be lower than that of the raw samples. The authors attributed the reduction to denaturation in the processed samples. The protein content of African yam bean accessions in this study was higher than the $10.6-11.7 \%$ previously reported by Nyananyo and Nyingifa [34] and agreed with the findings of Eromosele et al. [35] that reported values of $21-29 \%$ for the protein content of African yam bean and also within the range of $9.9-23.7 \%$ as well as the range of 19.3 to $25.6 \%$ reported by Ojuederie [36].

However, it was less than $26.68 \%$ as previously reported [37]; 37.2\% for AYB and 32.4\% were reported for Bambara groundnut by Chinedu and Nwinyi [27] and 32.5\% for Winged bean [38]. Studies have shown that any plant food that provides about $12 \%$ of its calorific value from protein is considered a good source of protein [39, 40]. African yam bean with a good proportion of high protein and carbohydrate contents could be a promising food crop that can be useful in combating protein-energy malnutrition. Clinical studies had shown that when legumes replaced carbohydrate-rich foods, legumes reduced glucose elevations in both diabetic and nondiabetic participants. Legumes lowered fasting blood glucose in 11 other trials [41]. Obese men that ate legumes at least four times a week experienced a significant reduction in waist circumference, body mass fat, blood pressure, and total cholesterol [42].

Crude fat in processed seed was $2.38 \%$ (TSs1) and $0.37 \%$ (TSs68); in the unprocessed seed, 2.62\% (TSs24) and $1.31 \%$ (TSs4) were obtained for African yam bean accessions and were lower than other crude legumes, such as soybean (28.2\%) as per Ogbemudia et al. [43] and groundnut (46.1\%) [44]. Fat and oil in legumes are usually healthy for human consumption because of their unsaturated nature. The lowfat content of African yam bean seed makes it ideal as a promising food crop for weight management. It also enhances the processing of the seed to the flour without going through the defatting stage in flour production [42]. Furthermore, due to the low content of fat when compared with nuts such as almonds, hazelnuts, and walnuts, African yam bean has low caloric value, which makes it an interesting healthy food; however, it also limits its use for commercial oil production. This is because high-fat diets lead to increased levels of blood cholesterol and heart attacks [45].

The carbohydrate content of African yam bean seed was very high compared to results obtained for winged bean, soybean, peanut, cowpea, and chickpea [46]. The unprocessed samples recorded higher carbohydrate content, which did not support an earlier report by Agiang et al. [47] that suggested that processing causes the granules to break down and makes the starch more available. The carbohydrate content of the seed-in processed seed, TSs9 (62.93\%) to TSs1 (29.64\%), while in unprocessed seed, TSs4 (67.36\%) and TSs38 (54.23\%)—was similar but higher when compared to previous studies, $42.77-62.76 \%$ reported for Bambara groundnut by Atoyebi et al. [48], 54.31-59.64\% for lima bean by Yellavila et al. [49], and 38.18-56.96\% for cowpea by Mamiro et al. [50]. Legumes are especially high in resistant starch, generally defined as starch and starch products not digested in the small intestine [42]. Legumes also have a low glycemic index (GI) compared with other carbohydrate-rich foods, likely to be as a result of both their resistant starch and fiber. The low GI of legumes can potentially produce clinically relevant importance [51].

The moisture content (mc) for all the samples, processed and unprocessed, falls within the recommended range of $0-13 \%$ [52]. It has been reported that the optimum mc for pulses is in the range of $9-12 \%$ to avoid the production of mycotoxins and for safe storage. At a moisture level below $10 \%$, respiration in most food grain almost stops, increasing grain storage life [53]. The moisture content of the African yam bean accessions analyzed was less than $10 \%$ and fell within the optimum $\mathrm{mc}$ range for safe storage of pulses. The low mc analyzed explains why dry African yam bean seeds obtained from pods harvested during the dry season (without any additional drying after harvest) can be stored in 
polyethylene bags for several months at room temperature without microbial growth and deterioration [42]. The values obtained in this study were less than the results reported by Ojuederie [36] with higher values of 11.3 to $12.6 \%$.

The crude fiber represents the amount of indigestible sugar present in the sample and was generally better than that from most seeds as well as that obtained in eastern Nigeria $[33,54]$. Reports have shown that diets that are low in fiber are unpleasant as they could cause constipation and have been associated with diseases of the colon, such as piles, appendicitis, and cancer [55]. The level of fiber for African yam bean in this study was higher than that found in groundnut (2.83\%) by Ayoola et al. [44] but lower than that (10.37-17.21\%) found in cowpea by Mamiro et al. [50].

The ash content $(3.94-3.20 \%$ in processed seed and $3.99-3.06 \%$ in the unprocessed seed of the African yam bean accessions studied) agreed with that reported for African yam bean (4.30\%) [56]. The ash content of the African yam bean accessions studied was lower than that obtained for African yam bean (5.35\%) by Chinedu and Nwinyi [27] but higher than the ash content of common bean (3.26\%), mung bean $(3.82 \%)$, pigeon pea (3.55\%), black-eyed bean $(3.41 \%)$, and soybean (4.01\%) by Anhwange et al. [57]. Since the ash content of a seed is the measure of its mineral content of a material, the level of ash recorded in African yam bean suggested it might be a good source of dietary minerals.

Legumes have been reported to possess antinutritional factors (ANFs) which affect their nutritional quality. The ANFs are capable of changing the taste, protein digestibility, and bioavailability of nutrients $[58,59]$. They can be toxic and may negatively affect the nutrient value of seeds by impairing protein digestibility and mineral availability. However, they are heat-labile and hence may be inactivated by processing methods involving heat generation. On the other hand, a number of the compounds, such as phytic acid, phenols, and tannins, usually considered antinutritional compounds, are currently considered potential antioxidants containing health-promoting effects. For example, phytic acid has now been revealed to have rich antioxidant, hypoglycaemic activities and also to possess anticarcinogenic properties. Therefore, elimination of these compounds depends upon the consumer's preferences [60].

The results for ANFs in processed samples observed in the current study were similar to the report of Alamu [30] where there was a significant reduction in phytate, tannins, and trypsin inhibitor contents following cooking. In the same manner, tannin content of the seed of African yam bean and other legumes such as pigeon pea (Cajanus cajan) and cowpea (Vigna unguiculata) decreased with processing [31].

Phytic acid is considered an antinutrient because it forms insoluble complexes with minerals. Phytate chelates minerals (especially calcium and zinc) form poorly soluble compounds which are not voluntarily absorbed from the intestine, thus interfering with the bioavailability of these essential minerals as well as inhibiting enzymatic digestion of both starch and proteins [61]. Phytates can enhance the risk of mineral deficiencies sooner or later if animal food intake is low. They do not show the influence on the absorption of minerals from meat [62]. Phytates are an alarm in developing countries where regular diets are based on legumes and grains as they are vegetarians [63]. However, dehulling, soaking, boiling or steaming, roasting, sprouting, sun drying, and fermentation of legumes trigger an enzyme (phytase) which helps their breakdown $[61,64]$. On the other hand, phytates show useful health effects, having a positive role as an antioxidant and are a protection against a variety of cancers and coronary heart diseases, renal stones, and diabetes mellitus. Thus total removal of phytates may not be desirable [65]. Due to the presence of high fiber, they also help in the reduction of cholesterols and other lipids $[4,66]$.

Conventional food preparation techniques such as soaking, sprouting, boiling, and fermentation have been previously reported to improve flavor and palatability of legumes as well as to increase the bioavailability of nutrients, by deactivating antinutritional factors and also allowing the digestion and assimilation of starch and protein [67]. Hence, this shows why legumes should not be consumed raw.

The effects of heat treatment on antinutrients observed in the current study were similar to the report by Pugalenthi et al. [68] that showed that roasting reduced trypsin inhibitor activity. This may be as a result of the enhanced leaching of these antinutrients in the sample into the heated water and the denaturation of the protein trypsin inhibitor, by high temperature due to roasting. Nwosu [69] showed a significant reduction was shown in phytate, tannins, and trypsin inhibitor contents following cooking [61], which is in agreement with this study. In the same manner, tannin content of the seed of African yam bean and other legumes such as pigeon pea (C. cajan) and cowpea ( $V$. unguiculata) decreased with processing [70].

Phytic acid has also been reported to form insoluble complexes with minerals [71]. Generally, processing reduced the level of all the antinutrients analyzed to their permissible levels. This research has identified promising African yam bean accessions superior for nutrient quality traits analyzed. The best accession was TSs 104 in terms of crude protein, ash, crude fiber, carbohydrate, and lower tannin and phytate; TSs11, TSs3, and TSs9 were best in terms of carbohydrate content. Seeds of African yam bean are recommended for inclusion in human food preparation and consumption, also in fish and livestock feed meals, and as an alternative to animal protein for vegetarians. The variability with respect to these traits could be explored by breeding programs in developing improved African yam bean varieties with better qualities in terms of nutrient composition. The outcome of this current study agrees with the report of African yam bean seeds from Southern Kaduna, Northwest Nigeria. The authors reported varying levels of proximate, mineral, and antinutrients (high level protein, carbohydrate, lipid, minerals, and other nutrients) irrespective of the form in which the seeds are processed (raw, boiled or roasted) [72].

\section{Conclusions}

The results of the present study indicated that the African yam bean seeds have considerable good nutritional profiles with high levels of protein, carbohydrate, and other nutrients 
comparable with those of other common legumes. Seed processing by oven drying reduced the level of antinutrients with low effect on nutritional quality. In sub-Saharan Africa, African yam bean has great potential for combating proteinenergy malnutrition. Renewed efforts should be made towards increased cultivation by farmers, with a briefing on utilization such as a food nutrient for humans as well as livestock. The outcome of this study further revealed there is variability in the African yam bean accessions analyzed for proximate quality and antinutrients which can be explored in developing improved varieties.

\section{Data Availability}

The data used to support the findings of this study are available from the corresponding author upon request.

\section{Conflicts of Interest}

The authors declare no conflicts of interest.

\section{Acknowledgments}

The authors wish to appreciate IITA for the provision of the Graduate Research Fellowship Award to the first author. The kind assistance rendered by the entire staff of the Genetic Resources Center, IITA, during the field experiments, is acknowledged. The authors are also deeply grateful to the staff of Food and Nutrition Sciences and Soil Microbiology laboratories of IITA in analyzing and processing the samples. The work of GRC was funded by the Global Crop Diversity Trust and CGIAR.

\section{References}

[1] C. K. Khoury, "The conservation and use of crop genetic resources for food security", Ph.D. thesis, Wageningen University, Wageningen, Netherlands, 2015.

[2] V. Sardana, P. Sharma, and P. Sheoran, "Soils, plant growth and crop production, in growth and production of pulses," Encyclopedia of Life Support Systems, pp. 5-44, UNESCO, Paris, France, 2010.

[3] M. Gebrelibanos, "Nutritional and health implications of legumes," International Journal of Pharmaceutical Sciences and Research, vol. 4, no. 4, pp. 1269-1279, 2013.

[4] R. Kamboj and V. Nanda, "Proximate composition, nutritional profile and health benefits of legumes-a review," Legume Research-An International Journal, vol. 41, no. 3, pp. 325-332, 2017.

[5] A. N. Mudryj, N. Yu, and H. M. Aukema, "Nutritional and health benefits of pulses," Applied Physiology, Nutrition, and Metabolism, vol. 39, no. 11, pp. 1197-1204, 2014.

[6] C. Cullis and K. J. Kunert, "Unlocking the potential of orphan legumes," Journal of Experimental Botany, vol. 68, no. 8, pp. 1895-1903, 2017.

[7] M. Aremu, H. Ibrahim, and B. Ekanem, "Effect of processing on in-vitro protein digestibility and anti-nutritional properties of three underutilized legumes grown in Nigeria," British Biotechnology Journal, vol. 14, no. 1, 2016.

[8] T. Mabhaudhi, V. G. Chimonyo, and A. T. Modi, "Status of underutilised crops in South Africa: opportunities for developing research capacity," Sustainability, vol. 9, no. 9, p. $1569,2017$.

[9] K. G. Duodu and F. B. Apea-Bah, "African legumes: nutritional and health-promoting attributes," in Gluten-Free Ancient Grains, pp. 223-269, Elsevier, Amsterdam, Netherlands, 2017.

[10] P. Lepcha, A. N. Egan, J. J. Doyle, and N. Sathyanarayana, “A review on current status and future prospects of winged bean (Psophocarpus tetragonolobus) in tropical agriculture," Plant Foods for Human Nutrition, vol. 72, no. 3, pp. 225-235, 2017.

[11] J. C. Clark and M. N. Raizada, "Climbing legumes: an underutilized resource with significant potential to intensify farming on terrace walls (FTW) for smallholder farmers," 2017, https://www.biorxiv.org/content/10.1101/184952v1.

[12] M. Gulzar and A. Minnaar, "Underutilized protein resources from African legumes," in Sustainable Protein Sources, pp. 197-208, Elsevier, Amsterdam, Netherlands, 2016.

[13] J. Chacha, The Potential Role of Underutilized Vegetables in Improving Food and Nutrition Security in Tanzania, Sokoine University of Agriculture, Morogoro, Tanzania, 2017.

[14] J. Grebosz, "Volatile organic compounds in food security: the role of neglected and underutilized legumes," in Volatiles and Food Security, pp. 81-111, Springer, Berlin, Germany, 2017.

[15] S. Yang, A. Grall, and M. A. Chapman, "Origin and diversification of winged bean (Psophocarpus tetragonolobus (L.) DC.), a multipurpose underutilized legume," American Journal of Botany, vol. 105, no. 5, pp. 888-897, 2018.

[16] D. T. Ishola, "Comparative evaluation of the proximate composition of raw and fermented seeds of Zarmarkee sesbania spp," IOSR Journal of Agriculture and Veterinary Science (IOSR-JAVS), vol. 11, no. 6, pp. 20-25, 2018.

[17] S. R. Kaoneka, R. K. Saxena, S. N. Silim et al., "Pigeonpea breeding in eastern and southern Africa: challenges and opportunities," Plant Breeding, vol. 135, no. 2, pp. 148-154, 2016.

[18] M. Ogwu, C. Ahana, and M. Osawaru, "Sustainable food production in Nigeria: a case study for Bambara groundnut (Vigna subterranea (L.) Verdc. fabaceae)," Journal of Energy and Natural Resource Management (JENRM), vol. 1, p. 1, 2018.

[19] A. B. Daniel and O. N. Celestina, "A review on genetic resources, diversity and agronomy of African yam bean (Sphenostylis stenocarpa (Hochst. Ex A. rich.) harms): a potential future food crop," Sustainable Agriculture Research, vol. 2, no. 1, pp. 32-43, 2013.

[20] D. B. Adewale and A. E. Adegbite, "Investigation of the breeding mechanism of African yam bean [fabaceae] (sphenostylis stenocarpa hochst. ex. A. rich) harms," Notulae Scientia Biologicae, vol. 10, no. 2, pp. 199-204, 2018.

[21] E. Ohanmu, B. Ikhajiagbe, and B. Edegbai, "Nitrogen distribution pattern of African yam bean (Sphenostylis stenocarpa) exposed to cadmium stress," Journal of Applied Sciences and Environmental Management, vol. 22, no. 7, pp. 1053-1057, 2018.

[22] D. Porter, "Economic botany of sphenostylis (leguminosae)," Economic Botany, vol. 46, no. 3, pp. 262-275, 1992.

[23] P. A. Okorie, "Assessing the anti-nutritional composition of four varieties of African yam bean in Afikpo town of Ebonyi state Nigeria," International Journal of Modern Research in Engineering and Technology (IJMRET), vol. 3, no. 6, pp. 1-4, 2018.

[24] H. N. Ene-Obong and E. Carnovale, "A comparison of the proximate, mineral and amino acid composition of some known and lesser known legumes in Nigeria," Food Chemistry, vol. 43, no. 3, pp. 169-175, 1992. 
[25] N. N. Uchegbu and F. Amulu, "Effect of germination on proximate, available phenol and flavonoid content, and antioxidant activities of African yam bean (Sphenostylis stenocarpa)," International Journal of Biological, Biomolecular, Agricultural, Food and Biotechnological Engineering, vol. 9, no. 1, pp. 106-109, 2015.

[26] M. Iwe, U. Onyeukwu, and A. Agiriga, "Proximate, functional and pasting properties of FARO 44 rice, African yam bean and brown cowpea seeds composite flour," Cogent Food \& Agriculture, vol. 2, no. 1, Article ID 1142409, 2016.

[27] S. N. Chinedu and C. O. Nwinyi, "Proximate analysis of Sphenostylis stenocarpa and voadzeia subterranean consumed in south eastern Nigeria," Journal of Agricultural Extension and Rural Development, vol. 4, no. 3, pp. 57-62, 2012.

[28] J. N. Nwosu, "Evaluation of the proximate composition and antinutritional properties of African yam bean (Sphenostylis sternocarpa) using malting treatment," International Journal of Basic and Applied Sciences, vol. 2, no. 4, pp. 157-169, 2013.

[29] O. O. Oyebiyi, J. O. Ojetade, S. A. Muda, and A. A. Amusan, "Comparative study of three methods of determining cation exchange capacity of three major soils in the rainforest region of southwestern Nigeria," Communications in Soil Science and Plant Analysis, vol. 49, no. 18, pp. 2338-2344, 2018.

[30] E. Alamu, B. Maziya-Dixon, I. Popoola, T. Gondwe, and D. Chikoye, "Nutritional evaluation and consumer preference of legume fortified maize-meal porridge," Journal of Food and Nutrition Research, vol. 4, no. 10, pp. 664-670, 2016.

[31] M. Adegunwa, E. Alamu, and L. Omitogun, "Effect of processing on the nutritional contents of yam and cocoyam tubers," Journal of Applied Bioscience, vol. 46, pp. 3086-3092, 2011.

[32] E. Wheeler and R. Ferrel, "A method for phytic acid determination in wheat and wheat fractions," Cereal Chemistry, vol. 48, no. 3, pp. 312-320, 1971.

[33] M. O. Adegunwa, A. A. Adebowale, and E. O. Solano, "Effect of thermal processing on the biochemical composition, antinutritional factors and functional properties of beniseed (Sesamum indicum) flour," American Journal of Biochemistry and Molecular Biology, vol. 2, no. 3, pp. 175-182, 2012.

[34] B. Nyananyo and A. Nyingifa, "Phytochemical investigation on the seed of Sphenostylis stenocarpa (hochst ex A. rich.) harms (family fabaceae)," Journal of Applied Sciences and Environmental Management, vol. 15, no. 3, pp. 419-423, 2011.

[35] C. O. Eromosele, L. A. Arogundade, I. C. Eromosele, and O. Ademuyiwa, "Extractability of African yam bean (Sphenostylis stenocarpa) protein in acid, salt and alkaline aqueous media," Food Hydrocolloids, vol. 22, no. 8, pp. 1622-1628, 2008.

[36] O. B. Ojuederie, "Genetic variation in nutritional propoerties of African yam bean (Sphenostylis stenocarpa Hochst ex. A. rich. harms) accessions," Nigerian Journal of Agriculture, Food and Environment, vol. 13, no. 1, pp. 180-187, 2017.

[37] G. O. Ajibola and A. A. Olapade, "Physical, proximate and anti-nutritional composition of African yam bean (Sphenostylis stenocarpa) seeds varieties," Journal of Food Research, vol. 5, no. 2, p. 67, 2016.

[38] M. Sankaran, N. Singh, and J. Prakash, "Genetic resources of underutilized horticultural crops in tripura," Underutilized and Underexploited Horticultural Crops, pp. 1-20, New India Publishing Agency, New Delhi, India, 2007.

[39] G. Effiong, T. Ibia, and U. Udofia, "Nutritive and energy values of some wild fruit spices in Southeastern Nigerian,"
Electronic Journal of Environmental, Agricultural \& Food Chemistry, vol. 8, no. 10, 2009.

[40] A. Aberoumand, "A comparative study of nutrients and mineral molar ratios of some plant foods with recommended dietary allowances," Advance Journal of Food Science and Technology, vol. 2, no. 2, pp. 104-108, 2010.

[41] S. V. Thompson, D. M. Winham, and A. M. Hutchins, "Bean and rice meals reduce postprandial glycemic response in adults with type 2 diabetes: a cross-over study," Nutrition Journal, vol. 11, no. 1, p. 23, 2012.

[42] S. O. Baiyeri, M. I. Uguru, P. E. Ogbonna et al., "Evaluation of the nutritional composition of the seeds of some selected African yam bean (Sphenostylis stenocarpa Hochst ex. A. rich (harms)) accessions," Agro-Science, vol. 17, no. 2, pp. 37-44, 2018.

[43] R. E. Ogbemudia, N. B. Chika, and A. Benedicta, "Mineral and proximate composition of soya bean," Asian Journal of Physical and Chemical Science, vol. 4, no. 3, pp. 1-6, 2017.

[44] P. Ayoola, A. Adeyeye, and O. Onawumi, "Chemical evaluation of food value of groundnut (Arachi hypogaea) seeds," American Journal of Food and Nutrition, vol. 2, no. 3, pp. 55-57, 2012.

[45] M. Hession, C. Rolland, U. Kulkarni, A. Wise, and J. Broom, "Systematic review of randomized controlled trials of lowcarbohydrate vs. low-fat/low-calorie diets in the management of obesity and its comorbidities," Obesity Reviews, vol. 10, no. 1, pp. 36-50, 2009.

[46] T. E. Ekpenyong and R. L. Borchers, Nutritional Aspect of the Winged Bean, in Proceedings of the 1st International Symposium on Developing the Potentials of the Winged Bean, pp. 300-312, Manila, Philippines, 1978.

[47] M. A. Agiang, I. B. Umoh, A. I. Essien, and M. U. Eteng, "Nutrient changes and antinutrient contents of beniseed and beniseed soup during cooking using a Nigerian traditional method," Pakistan Journal of Biological Sciences, vol. 13, no. 20, pp. 1011-1015, 2010.

[48] J. O. Atoyebi, O. Osilesi, O. Adebawo, and M. Abberton, "Evaluation of nutrient parameters of selected African accessions of Bambara groundnut (Vigna subterranea (L.) verdc.)," American Journal of Food and Nutrition, vol. 5, no. 3, pp. 83-89, 2017.

[49] S. Yellavila, J. K. Agbenorhevi, J. Y. Asibuo, and G. O. Sampson, "Proximate composition, minerals content and functional properties of five lima bean accessions," Journal of Food Security, vol. 3, no. 3, pp. 69-74, 2015.

[50] P. Mamiro, A. M. Mbwaga, D. P. Mamiro, A. W. Mwanri, A. W. Mwanri, and J. L. Kinabo, "Nutritional quality and utilization of local and improved cowpea varieties in some regions in Tanzania," African Journal of Food, Agriculture, Nutrition and Development, vol. 11, no. 1, pp. 4490-4502, 2011.

[51] V. Messina, "Nutritional and health benefits of dried beans," The American Journal of Clinical Nutrition, vol. 100, no. suppl_1, pp. 437S-442S, 2014.

[52] C. S. James, Analytical Chemistry of Foods, Chapman \& Hall, New York, NY, USA, 1st edition, 1995.

[53] J. A. R. Sujeetha, C. K. Abirami, and K. Alagusundaram, "Biointensive safe storage methods for pulses," Journal of Biopesticides, vol. 7, no. 1, p. 98, 2014.

[54] O. A. Ojiako, C. A. Ogbuji, N. C. Agha, and V. A. Onwuliri, "The proximate, mineral, and toxicant compositions of four possible food security crops from southeastern Nigeria," Journal of Medicinal Food, vol. 13, no. 5, pp. 1203-1209, 2010. 
[55] B. Okon, "Studies on the chemical composition and nutritive value of the fruits of African star apple," M.Sc. thesis, University of Calabar, Calabar, Nigeria, 1983.

[56] G. Adamu, O. Ezeokoli, A. Dawodu, A. Adebayo-Oyetoro, and L. Ofodile, "Macronutrients and micronutrients profile of some underutilized beans in south western Nigeria," International Journal of Biochemistry Research \& Review, vol. 7, no. 2, pp. 80-89, 2015.

[57] B. Anhwange, V. Ajibola, and S. Oniye, "Amino acid composition of the seeds of moringa oleifera (lam), Detarium microcarpum (guill \& sperr) and Bauhinia monandra (linn.)," ChemClass Journal, vol. 1, pp. 9-13, 2004.

[58] A. K. Jain, S. Kumar, and J. Panwar, "Antinutritional factors and their detoxification in pulses-a review," Energy, vol. 30, no. 1, pp. 64-70, 2009.

[59] N. Kalogeropoulos, A. Chiou, M. Ioannou, V. T. Karathanos, M. Hassapidou, and N. K. Andrikopoulos, "Nutritional evaluation and bioactive microconstituents (phytosterols, tocopherols, polyphenols, triterpenic acids) in cooked dry legumes usually consumed in the Mediterranean countries," Food Chemistry, vol. 121, no. 3, pp. 682-690, 2010.

[60] R. Bhat and A. A. Karim, "Exploring the nutritional potential of wild and underutilized legumes," Comprehensive Reviews in Food Science and Food Safety, vol. 8, no. 4, pp. 305-331, 2009.

[61] R. S. Gibson, A.-L. M. Heath, and E. A. Szymlek-Gay, "Is iron and zinc nutrition a concern for vegetarian infants and young children in industrialized countries?" The American Journal of Clinical Nutrition, vol. 100, no. 1, pp. 459S-468S, 2014.

[62] C. Uzel and M. E. Conrad, "Absorption of Heme iron," Seminars in Hematology, vol. 35, no. 1, pp. 27-34, 1998.

[63] J. R. Hunt, "Bioavailability of iron, zinc, and other trace minerals from vegetarian diets," The American Journal of Clinical Nutrition, vol. 78, no. 3, pp. 633S-639S, 2003.

[64] W. T. Lee, R. Weisell, J. Albert, D. Tomé, A. V. Kurpad, and R. Uauy, "Research approaches and methods for evaluating the protein quality of human foods proposed by an FAO expert working group in 2014," The Journal of Nutrition, vol. 146, no. 5, pp. 929-932, 2016.

[65] V. Kumar, A. K. Sinha, H. P. S. Makkar, and K. Becker, "Dietary roles of phytate and phytase in human nutrition: a review," Food Chemistry, vol. 120, no. 4, pp. 945-959, 2010.

[66] K. Midorikawa, M. Murata, S. Oikawa, Y. Hiraku, and S. Kawanishi, "Protective effect of phytic acid on oxidative DNA damage with reference to cancer chemoprevention," Biochemical and Biophysical Research Communications, vol. 288, no. 3, pp. 552-557, 2001.

[67] B. Xu and S. K. C. Chang, "Effect of soaking, boiling, and steaming on total phenolic contentand antioxidant activities of cool season food legumes," Food Chemistry, vol. 110, no. 1, pp. 1-13, 2008.

[68] M. Pugalenthi, V. Vadivel, P. Gurumoorthi, and K. Janardhanan, "Comparative nutritional evaluation of little known legumes, Tamarindus indica, Erythrina indica and Sesbania bispinosa," Tropical and Subtropical Agroecosystems, vol. 4, no. 3, 2004.

[69] J. Nwosu, "Effect of soaking, blanching and cooking on the antinutritional properties of asparagus bean (Vigna sesquipedis) flour," Nature and Science, vol. 8, no. 8, pp. 163-167, 2010.

[70] G. I. Onwuka, "Soaking, boiling and antinutritional factors in pigeon peas (Cajanus cajan) and cowpeas (Vigna unguiculata)," Journal of Food Processing and Preservation, vol. 30, no. 5, pp. 616-630, 2006.

[71] F. T. Ajayi, "Nutritive evaluation of some tropical underutilized grain legume seeds for ruminant's nutrition," Journal of American Science, vol. 6, no. 7, pp. 1-7, 2010.
[72] U. S. Ndidi, C. U. Ndidi, A. Olagunju, A. Muhammad, F. G. Billy, and O. Okpe, "Proximate, antinutrients and mineral composition of raw and processed (boiled and roasted) Sphenostylis stenocarpa seeds from Southern Kaduna, Northwest Nigeria," ISRN Nutrition, vol. 2014, Article ID 280837, 9 pages, 2014. 